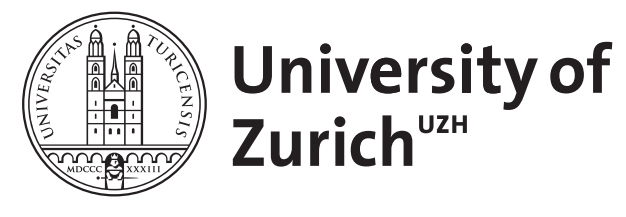

\title{
The Power of Banks and Governments
}

\author{
Reinke, Raphael
}

\begin{abstract}
This article examines Cornelia Woll's book on the "power of collective inaction" in which she argues that banks could extract favorable bailouts in the recent global financial crisis by remaining collectively inactive. Collective inaction forces governments to bear the brunt of the crisis resolutions. While this book provides an illuminating account of banking bailouts in several countries, its argument neglects the power of governments and of individual banks. Governments did not have to wait for banks' (in)action but could impose punitive conditions on banks. And the resistance by banks did not originate from an incapacity to act collectively but from deliberate actions by individual banks to obstruct government intrusion. Rather than <jats:italic $>$ inaction $</$ jats:italic $>$ on the part of banks, these interactions between governments and banks involved deliberate $<$ jats:italic $>$ action $</$ jats:italic $>$ and their outcome depended on more conventional notions of state-business power relations.
\end{abstract}

DOI: https://doi.org/10.1515/ael-2016-0003

Posted at the Zurich Open Repository and Archive, University of Zurich

ZORA URL: https://doi.org/10.5167/uzh-171954

Journal Article

Published Version

Originally published at:

Reinke, Raphael (2016). The Power of Banks and Governments. Accounting, Economics, and Law, 6(1):57-63.

DOI: https://doi.org/10.1515/ael-2016-0003 


\section{Raphael Reinke* \\ The Power of Banks and Governments}

DOI 10.1515/ael-2016-0003

Abstract: This article examines Cornelia Woll's book on the "power of collective inaction" in which she argues that banks could extract favorable bailouts in the recent global financial crisis by remaining collectively inactive. Collective inaction forces governments to bear the brunt of the crisis resolutions. While this book provides an illuminating account of banking bailouts in several countries, its argument neglects the power of governments and of individual banks. Governments did not have to wait for banks' (in)action but could impose punitive conditions on banks. And the resistance by banks did not originate from an incapacity to act collectively but from deliberate actions by individual banks to obstruct government intrusion. Rather than inaction on the part of banks, these interactions between governments and banks involved deliberate action and their outcome depended on more conventional notions of state-business power relations.

Keywords: political economy, business power, banking bailouts

\section{Table of contents}

1 Examining Banking Bailouts

2 The Power of Inaction

3 The Power of Action and the Power of the State References

\section{Symposium on 'The Power of Inaction. Bank Bailouts in Comparison' by Cornelia Woll}

1 Cornelia, Woll (2016) 'A Symposium on Financial Power', Accounting, Economics and Law: A Convivium, DOI 10.1515/ael-2016-0001.

2 Kelsey M. Barnes and Arthur E. Wilmarth (2016) 'Explaining Variations in Bailout Policies: A Review of Cornelia Woll's The Power of Inaction', Accounting, Economics and Law: A Convivium, DOI 10.1515/ael-2015-0012.

3 Matthias Thiemann (2016) 'The Power of Inaction or Elite Failure? A Comment on Woll' “The Power of Inaction", Accounting, Economics and Law: A Convivium, DOI 10.1515/ael-2015-0011.

4 Philippe Moutot (2016) 'Power of Inaction or Ability to Learn in Action within a Political Process? Comments on “The Power of Inaction” by Cornelia Woll', Accounting, Economics and Law: A Convivium, DOI 10.1515/ael-2015-0009.

*Corresponding author: Raphael Reinke, Department of Political Science, University of Zurich, Affolternstrasse 56, Zurich 8050, Switzerland, E-mail: reinke@ipz.uzh.ch 
5 Raphael Reinke (2016) 'The Power of Banks and Governments', Accounting, Economics and Law: A Convivium, DOI 10.1515/ael-2016-0003.

6 Jason O. Jensen (2016) 'Comment on The Power of Inaction by Cornelia Woll', Accounting, Economics and Law: A Convivium, DOI 10.1515/ael-2015-0010.

7 Yuri Biondi (2016) 'Empowering Market-Based Finance: A Note on Bank Bailouts in the Aftermath of the North Atlantic Financial Crisis of 2007', Accounting, Economics and Law: A Convivium, DOI 10.1515/ael-2016-0004.

8 Cornelia Woll (2016) 'A Rejoinder by the Author', Accounting, Economics and Law: A Convivium, DOI 10.1515/ael-2016-0005.

\section{Examining Banking Bailouts}

In "The Power of Inaction", Cornelia Woll examines the six largest bank bailouts during the global financial crisis after the failure of Lehman Brothers in the fall of 2008. For these bailouts, the governments spent billions of dollars to save banks from collapsing and risked multiples of their economies' output by granting state guarantees on banks' liabilities. Considering the prolonged recession in the aftermath of the crisis, Woll addresses the pertinent issue of banks' power to dump their risks onto the state.

Woll's book provides an in-depth and rich study of the recent bailouts, which no other available volume matches. She pays attention to important and often-neglected aspects around bailouts, like the structure of the financial sector and the interaction among banks. With her comparative approach, Woll also goes beyond the commonplace that banks are powerful. While recognizing that banks are generally influential, she shows convincingly that banks in some countries could wring generous bailouts from the government, while in others, they ended up paying dearly. Although I am not convinced of her argument about the power of collective inaction, I find the book to be a major advance in the debate about the politics of banking bailouts with a rich presentation of crisis events based inter alia on her own interviews.

\section{The Power of Inaction}

Woll starts the book with the collapse of Lehman Brothers, when the US government and banks failed to arrange a rescue. About this episode, $\mathrm{H}$. Rodgin Cohen, a Wall-Street lawyer Woll quotes, said that he had the impression the government was "playing a game of chicken or poker" (Financial Crisis 
Inquiry Commission, 2011, p.334; Woll, 2014, p.2). She takes up this game-ofchicken metaphor and argues that governments and banks find themselves in a comparable confrontation. During crises, banks and governments can either stay on course doing nothing, or they can yield. The one who yields loses this game and has to bear the costs. And if both the government and the banks do nothing, they cause a financial crash.

Here, Woll adds a twist to this game. "But if the financial industry knows that the government will not let this happen, their best strategy is to be uncoordinated and benefit from a bank bailout scheme financed entirely through the public budget" (Woll, 2014, p.59). This twist is Woll's "power of in-action." If banks are unwilling or incapable to act, they impel the government to give in and rescue the financial system. Woll (2014, pp.58f) argues that banks avoid this risky strategy and cooperate with the government if they individually believe the other banks cooperate, if they have experienced a crisis before, and if they can exchange among each other.

Whether banks or governments yield, Woll (2014, p.62) argues, matters for taxpayers. If banks give in and cooperate, they share the burden of the bailout. In this case, banks pay, and the costs to taxpayers are small. If banks resist, the costs to taxpayers depend on whether the government acts decisively and imposes a tough resolution.

The financial crisis caused havoc not only in the United States but affected, unfortunately, also a large number of other countries. The welcome side-effect for a comparativist is that the quick spread of the crisis offers a unique possibility to analyze similar business-government interactions. Woll analyzes the bailouts in six advanced economies and compares them in pairs across different institutional systems: The United Kingdom and the United States, Germany and France, and Ireland and Denmark. In all these countries, except Ireland, the governments tried to include banks in a cooperative crisis resolution. In Denmark and France, the banks cooperated and this cooperation kept the costs for the state small. For Germany, Woll finds that the divisions in the banking sector precluded a cooperative solution which prompted the government to intervene with large losses for the taxpayer. In the two liberal market economies, the United States and the United Kingdom, neither banking sector had a tradition of cooperation and could not easily exchange among each other. Woll (2014, p.107ff) argues (contrary to Culpepper \& Reinke, 2014, see below) that the ultimate outcome in the United Kingdom was punitive compared to the United States. And the reason for the punitive solution was that the British government recognized the coordination difficulties early and imposed its own solution. 


\section{The Power of Action and the Power of the State}

Woll proposes a rich argument and presents fascinating case studies which contribute much to our understanding about banking bailouts. However, I take issue with four points that ultimately address Woll's portrayal of power relations between governments and banks. First, I am not convinced by her argument that a well-organized banking sector should act less strategically than a fragmented sector, and second, that it is banks' incapacity to act collectively that forced governments' hands. Rather, I see costly bailouts as a result of healthier banks' unwillingness to cooperate. Third, Woll suggests that governments can bully banks into accepting though rescue plans, but she does not specify the limits of governments' power or why not all governments pursued this strategy. Finally, the negotiations about the large bailout programs did not center around a binary choice (yielding or not yielding), as Woll argues, but around the terms of the bailouts including the distribution of costs. In this section, I elaborate on these four points.

The "power of inaction" implies a certain "powerlessness of action." That is, banks in a financial sector that can organize will recognize the public-good nature of financial stability and bear the bailout costs. As a theoretical motivation, Woll (2014, p.59) points to Ostrom's (2000a, 2000b) contributions about social norms and people's ability to produce public goods. However, judging from banks behavior at other times (involving fraud, the rigging of interest rates, and their continued risk taking that produced the public "bad" - the financial crisis - that made the bailouts necessary), it is doubtful that banks really behave like the people Ostrom observed. Rather, I would argue, banks and their managers act strategically in their own narrow interests. If this is the case, it becomes unclear why a well-organized banking sector should be more inclined to pay for the bailout. In the logic of the chicken game, the capacity for action should then be as powerful as inaction.

Framing the argument in terms of this game, Woll stresses the collectiveaction component among banks, and she refers to the history of cooperation in the banking sector. This focus distracts, however, from a crucial difference between banks and from the role (or "action") of stable banks. During financial crises, not all banks suffer to the same extent, and those that are less affected enjoy greater bargaining power vis-à-vis the government. Failing banks, those that run out of funding, depend entirely on government liquidity. When these banks negotiate with the government, they have very little leverage. They want and need government support, be it guarantees or state capital (including partial 
nationalization). Banks like Lehman Brothers, RBS or Commerzbank could not make demands; they had to accept any government decision - and any decisions by other banks. However, not all banks were as vulnerable as Lehman Brothers or RBS. Some banks had sturdier funding structures and healthier balance sheets (Cornett, McNutt, Strahan, \& Tehranian, 2011). They obtained liquidity either through markets, including retail deposits, or in exchange for collateral from central banks, which had launched large liquidity programs (Lenza, Pill, \& Reichlin, 2010). Thus, these financially healthier banks did not depend in the same way on fiscal government bailouts and were in a much better negotiation position, particularly if they were highly internationalized. Internationalized banks are not reliant on one national economy and can thus eschew the pressure from the that country's financial regulators (Culpepper \& Reinke, 2014). While these banks welcomed liquidity and debt-guarantee programs, they opposed state recapitalizations. Accepting state capital would make the government a partial shareholder, allowing it to participate in future profits. Particularly for healthier banks with good prospects of recovery after the immediate crisis, the government's profit participation through state capital would prove expensive (Congressional Budget Office, 2014; Congressional Oversight Panel, 2011). For this reason, these banks opposed inclusive bailout programs that would place capital not only into failing banks, but into all banks. This difference in interests and the capacity of stable, internationalized banks to act suggest that non-cooperation may result less from "incapacity" and more from "unwillingness" to act collectively (Woll, 2014, p.7). While Woll (2014, pp.171f) recognizes a role of healthy banks, her argument sidetracks from their importance. A failure of collective action differs substantially from willful obstruction.

How could the government react in the face of banks' unwillingness to cooperate? Unfortunately, Woll remains ambiguous about the power of governments. Woll (2014, p.63) maintains that, in the face of financial sector resistance, governments can impose a crisis resolution with harsh conditions for failing banks. Her example for this stern bailout is the United Kingdom where the government forced strict conditions on failing banks. This part of the argument suggests that the government retains some form of power over banks - regardless of their inability to organize. Woll (2014, p.63) states that "it is best [for the government] to act unilaterally and impose a government solution," but she does not specify the scope and limits of the government's power. Central to the argument would be to know under which conditions does (or can) the governments impose a punitive or even an inclusive solution. The role of state power is particularly pertinent given that, in four of the six cases, the government faced a non-cooperative banking sector. 
This part of Woll's argument (about the ability of governments to bully banks) casts doubt on the appropriateness of game-of-chicken metaphor. Using this metaphor, Woll portrays bailouts as a confrontation in which banks and governments face the binary choice of yielding or not yielding; between agreeing to pay or risking failure. This metaphor rings true when we think about the negotiations over Lehman Brothers: Everybody shied away from action, and this failure caused market turmoil around the world. The large bailouts occurred, however, in the fall of 2008 after Lehman collapsed. From then on, the bailout negotiations were not about whether there would be a rescue but, rather, over its terms. In all countries with banking crises, governments bailed out the banks. And in these negotiations, banks and governments fought over which types of instruments should be used, which banks accept state capital and at which terms. Accordingly, the negotiation outcomes differed substantially between countries. For instance, the British government demanded high interest rates (12\%) in exchange for state capital, but the healthier banks allowed banks to opt out of this program. The US government priced the capital at lower nominal rates (initially 5\% and 9\% after five years) but allowed none of the major banks to opt out and additionally required warrants (i. e. stock options), which allowed the government to reap the benefits of banks' recovery and generated a net gain from the bailout (Congressional Budget Office, 2014). ${ }^{1}$

1 This is the main reason why Woll's evaluation of the British American bailout differs from the one given in Culpepper and Reinke (2014). Woll judges the British bailout to be punitive because the government demanded $12 \%$ interest for its investments (as preferred shares) and because it fired the executives of the banks that had required government recapitalizations and restricted their remuneration. In contrast, the American government offered state capital at lower rates and didn't demand top bankers be sacked or their pay cut. Still, I argue that the American bailout was overall more punitive - for two reasons: First, the American recapitalization was not as cheap for banks as Woll suggests. In addition to the interest, the American government demanded warrants, which allowed it to participate in banks' future profits. These warrants raised the price for state capital significantly. (The warrants cost Goldman Sachs USD 1.1 billion or $11 \%$ of the capital injection [Congressional Oversight Panel (2011)]).

Second, for the major banks, participation was obligatory in the United States, but voluntary in the United Kingdom (even though the British government also tried to include all banks). The obligatory participation for the major banks meant that relatively healthy banks participated in the costs of bailouts by paying for the warrants. In the United Kingdom, however, the relatively healthy banks (like HSBS or Barclays) profited from the debt-guarantee program but did not share the bailout costs. At the same time, the British government (with its high nominal interest rate of $12 \%$ ) charged mostly itself: In the two rescued banks, the government owned a large share ( $83 \%$ in RBS, $41 \%$ in Lloyds [National Audit Office (2010, p.4)]). Thus, the interest payments that the government received directly reduced the value of the shares it owned in the bank. 
Going back to the characterization by the Wall Street lawyer H. Rodgin Cohen, the bailout negations may resemble not so much a "game of chicken", but a "game of poker" (Woll, 2014, p.2). Who wins depends not merely on who blinks first, but who holds the stronger hand. The outcome of bailout negotiations results not from an incapacity to act, but from the capacity to force the other side to give in.

In conclusion, Cornelia Woll's book provides deep insights into the banking bailouts of the largest financial crisis in recent history. It sheds light on the calculus of banks and governments and argues provocatively that banks' power rests in in-action. Behind that in-action, however, there is surely a more conventional struggle between banks and the governments - each with their own sources of power.

\section{References}

Congressional Budget Office. (2014). Report on the troubled asset relief program-April 2014. Washington, DC.

Congressional Oversight Panel. (2011). March oversight report - the final report of the congressional oversight panel. Washington, DC: Congressional Oversight Panel.

Cornett, M. M., McNutt, J. J., Strahan, P. E., \& Tehranian, H. (2011). Liquidity risk management and credit supply in the financial crisis. Journal of Financial Economics, 101(2), 297-312.

Culpepper, P. D., \& Reinke, R. (2014). Structural power and bank bailouts in the United Kingdom and the United States. Politics \& Society, 42(4), 427-454.

Financial Crisis Inquiry Commission (2011). The financial crisis inquiry report: Final report of the national commission on the causes of the financial and economic crisis in the United States. New York: Public Affairs.

Lenza, M., Pill, H., \& Reichlin, L. (2010). Monetary policy in exceptional times. Economic Policy, 62, 295-339.

National Audit Office. (2010), Maintaining the financial stability of UK banks: update on the support schemes: Report by the Comptroller and Auditor General. HC 676 Session 2010-2011, National Audit Office, London.

Ostrom, E. (2000a). Collective action and the evolution of social norms. The Journal of Economic Perspectives, 14(3), 137-158.

Ostrom, E. (2000b). Crowding out citizenship. Scandinavian Political Studies, 23(1), 3-16.

Woll, C. (2014). The power of inaction: Bank bailouts in comparison. Ithaca: Cornell University Press.

Overall, the American government generated a profit from the bank-bailout program, while the British government was left with losses. To be sure, the governance restrictions were stricter for the rescued banks in the British case, but both governments viewed restricting executive pay as a second-order issue given that they tried to restore financial stability and negotiated the distribution of risks worth billions of dollars (or pounds) between taxpayers and banks. For these reasons, and despite the harsher governance requirements for two rescued British banks, I find the American bailout program to be more punitive. 